\title{
Comparison of early experience laparoscopic versus open partial nephrectomy in terms of clinical, oncological and renal functional outcomes
}

\author{
Laparoskopik parsiyel nefrektomi erken dönem deneyiminin, açık parsiyel nefrektomi ile klinik, \\ onkolojik ve renal fonksiyonlar açısından karșılaștırılması
}

\author{
Mert Kilic ${ }^{1}$, Meftun Culpan ${ }^{2}$, Asif Yildirim², Turhan Caskurlu ${ }^{3}$ \\ 1 Amerikan Hospital, Istanbul, Turkey \\ 2 Istanbul Medeniyet University, Department of Urology, Istanbul, Turkey \\ 3 Atașehir Memorial Hospital, Istanbul, Turkey
}

Submitted: 2020-09-28

Accepted: 2021-02-03

\begin{abstract}
Correspondence
Mert Kılıç

Teşvikiye, Güzelbahçe Sk No: 20

34365, Istanbul / Turkey

e-mail: mert_ctf@hotmail.com

T: +905332416475

F: +902123112363

\section{ORCID \\ M.K. $\quad$ 0000-0003-1707-3890 \\ M.C. 0000-0001-8573-1192 \\ A.Y. $\quad 0000-0002-3386-971 X$}

T.C. $\quad 0000-0002-4471-2670$
\end{abstract}

This work is licensed under a Creative Commons Attribution-NonCommercial 4.0 International License.
Özet

Amaç: Laparoskopik parsiyel nefrektomi (LPN) minimal invaziv olmasına rağmen teknik olarak zor bir prosedürdür. Günümüzde halen birçok merkezde, T1 evre böbrek tümöründe açı parsiyel nefrektomi (APN) tek seçenek olarak sunulmaktadır. Biz bu çalıșmamızda erken dönem LPN sonuçlarımızı, klinik, onkolojik bulgular ve böbrek fonksiyonları açısından açık yöntemle karşılaştırmayı hedefledik.

Gereç ve Yöntemler: 2004-2013 yılları arasinda klinik evre T1 böbrek tümörü nedeniyle APN $(\mathrm{n}=55)$ veya LPN $(\mathrm{n}=26)$ uygulanan 81 hasta çalışmaya dahil edildi. Perioperatif ve postoperatif veriler retrospektif olarak karşılaştırıldı. APN ve LPN grupları için takip süreleri sırasıyla $72.9 \pm 41.1$ ve $47.6 \pm 32.4$ ayd 1 ( $<<0.05)$.

Bulgular: Ortalama tümör boyutu ve RENAL nefrometri skorları her iki grup için benzerdi. APN prosedürlerinin \% 15 'inde, LPN'lerin ise tamamında sıfır iskemi uygulandı. Kanama miktarı ve perioperatif transfüzyon oranları APN grubunda daha yüksekti. Komplikasyon oranları her iki grupta benzerdi. Altıncı ayda kreatinin klirensindeki azalma APN grubunda istatistiksel olarak anlamlı iken LPN'de stabildi. Pozitif cerrahi sınır oranları APN için \% 6.6 ve LPN için \% 17.6 idi, $p=$ 0.19 . LPN yapılan bir hastada lokal nüks gelişti ve nefrektomi yapıldı. APN yapılan bir hastada lokal nüks ve bir başkasında ise uzak metastaz gözlendi. Her iki hastada da tirozin kinaz inhibitörü ile tedavi edildi.

\section{Abstract}

Objective: Although laparoscopic partial nephrectomy (LPN) is minimally invasive, it is also a technically challenging procedure. Currently, open partial nephrectomy (OPN) remains the only alternative in many centers for $\mathrm{T} 1$ kidney tumors. We reported our initial experience of LPN compared to OPN regarding clinical, oncological findings and renal functions.

Material and Methods: Between 2004-2013, 81 patients who underwent OPN ( $\mathrm{n}=55)$ or LPN $(\mathrm{n}=26)$ for clinically $\mathrm{T} 1$ renal tumors were included. Perioperative and postoperative data were compared, retrospectively. Follow-up times for OPN and LPN groups were $72.9 \pm 41.1$ and $47.6 \pm$ 32.4 months, respectively $(\mathrm{p}<0.05)$.

Results: The mean tumor size and RENAL nephrometry scores were similar for both groups. Zero-ischemia was performed in all of the LPN and $15 \%$ of the OPN procedures. Estimated blood loss and perioperative transfusion rates were higher in OPN group. Complications including grade < 3 and $\geq 3$ did not differ significantly between the groups. The decrease in creatinine-clearance at 6 th month was statistically significant in OPN group, while stable in LPN. Positive surgical margin rates were $6.6 \%$ for OPN and $17.6 \%$ for LPN, $\mathrm{p}=0.19$. One patient in LPN developed local recurrence and underwent nephrectomy. In OPN group,one local recurrence and one distant metastasis were observed in two independent patients. Both patients recieved tyrosine kinase inhibitor.

The study was approved by the Ethic Committee of Istanbul Medeniyet University (Approval Number: 2020/0390). All research was performed in accordance with relevant guidelines/regulations, and informed consent was obtained from all participants. 
Sonuç: LPN teknik olarak zor bir prosedür olmasına karșın öğrenme evresinde klinik, onkolojik bulgular ve böbrek fonksiyonları açısından APN'ye benzer sonuçlar göstermiştir. Sıfır iskemi yöntemi ile kabul edilebilir perioperatif ve renal fonksiyonel sonuçlar elde edilerek LPN'nin erken dönem deneyimlerinde dahi güvenilirliği ve uygulanabilirliği gösterilmiştir.

Anahtar Kelimeler: laparoskopi; öğrenme eğrisi; parsiyel nefrektomi; renal kanser; cerrahi sınır; sıfır iskemi.
Conclusion: Although LPN is accepted as a technically challenging procedure, LPN provided comparable outcomes to OPN including clinical, oncological findings and renal functions, even in the early learning phase. Zero-ischemia technique for LPN was feasible and safe with favorable perioperative and renal functional outcomes.

Keywords: laparoscopy; learning curve; partial nephrectomy; renal cancer; surgical margins; zero-ischemia.

\section{INTRODUCTION}

Although partial nephrectomy (PN) is currently the standard treatment in T1 solid renal tumors, the choice for this very demanding operative technique -either open or minimal invasive (laparoscopic or robotic) -should base on surgeon's experience according to EAU guidelines (1). Open partial nephrectomy (OPN) has the largest clinical experience and longest follow-up data. However there are downsides of the surgery such as longer hospitalization time, a surgical incision, need for more analgesic use and perioperative morbidity(2). On the contrary, despite similar oncological results the difficulty in the technique and long learning curve are main disadvantages for laparoscopic technique(3). While robotic PN has shorter learning curve compared to pure laparoscopy which has an important effect on warm ischemia time (WIT)(4), not all institutions have access to Da Vinci platforms which makes laparoscopic PN still an important surgical technique in the minimal invasive surgical armamentarium for many centers.

In this study we aimed to compare our initial experience of laparoscopic partial nephrectomy to the open technique in regard to clinical, oncological and renal functional findings.

\section{MATERIAL AND METHODS}

This study was conducted following institutional review board approval, under protocol number 2020/0390. In this retrospective single center study we included 81 patients who underwent PN (55 open and 26 laparoscopic) between 2004-2013. While all of the open surgeries were performed by multiple experienced surgeons, laparoscopic procedures were done by two surgeons in initial their learning curve. Patients characteristics of total 81 patients were summarised in
Table 1. Mean age, gender and body mass index (BMI) were similar for each group. There was no significant difference in Charlson comorbidity index (CCI) between the two groups either. All patients had incidentally diagnosed solitary clinically $\mathrm{T} 1$ tumors. The mean tumor size were $39.7 \pm 15.61$ and $33.12 \pm 13.87$ in OPN and LPN groups, respectively $(\mathrm{p}=0.069)$. RENAL nephrometry scores were $5.62 \pm 1.62$ and $5.08 \pm 1.29$, respectively $(\mathrm{p}=0.148)$. Four patients $(5 \%)$ had solitary kidney and underwent OPN. Postoperative complications occurring within 3 months were recorded according Clavien-Dindo classification. Patients were followed-up with 3 month intervals in first year and 6 month intervals in second year and yearly thereafter. Physical exam and laboratory studies were done at each follow-up. Renal function was assessed by serum creatinine and creatinine-clearance calculated with Cockcroft- Gault formula prior to the operation and at every follow-up. First radiological evaluation was performed with abdominal ultrasonography (USG) at third postoperative month. At 6th month an abdominal computerized tomography (CT) or magnetic resonance imaging (MRI) was performed and then USG and CT /MRI were utilized alternately at 6 months intervals for two years. In addition, a chest $\mathrm{x}$-ray was performed at 6 th month and then yearly.

\section{Operation Technique}

OPN was performed using flank position either with a standard subcostal or intercostal lumbotomy. The renal artery and vein were dissected, and the renal artery was isolated. If needed Bulldog or Satinsky clamps were used when needed to control the artery. After the surgical margin was marked with cautery, the tumor was resected with the perirenal fatty tissue from the normal renal parenchyma using a sharp and blunt dissection method. The opened calyceal system and/or 
bleeding foci were controlled with $3 / 0$ polyglactin sutures. The parenchyma was closed with 0 or $2 / 0$ polyglactin sutures in an interrupted or continuous fashion.

In the laparoscopic technique, the transperitoneal approach was preferred in the anterior, anterolateral and lateral polar masses, and the retroperitoneal approach was preferred for the posterior and posteromedial masses. No warm ischemia was used in any of the laparoscopic cases. The parenchyma was closed continuously with the 0 or $2 / 0$ number polyglactin sutures with sliding Hem-o-lok clips. The use of hemostatic agents on the parenchyma was at surgeon's discretion.

\section{Statistical Analysis}

The distribution of variables was checked with the Kolmogorov Smirnov test. Student-t and Mann-Whitney $\mathrm{u}$ test was used in the analysis of parametric data. Paired sample $t$ and Wilcoxon test were used in repeat measurements. In the analysis of categorical data, chisquare and Fisher test were used. Statistical analysis was done with SPSS version 21.0. $\mathrm{P}<0.05$ considered to indicate statistical significance.

\section{RESULTS}

Fifty-five and 26 patients underwent OPN and LPN, respectively. There were no significant difference between the two groups regarding operation time (111.36 $\pm 21.66 \mathrm{~min}$ vs. $107.50 \pm 19.56 \mathrm{~min}$ for OPN and LPN, respectively, $\mathrm{p}=0.442)$. In $30(54.5 \%)$ of $\mathrm{OPN}$ and 24 (92.3\%) of LPN cases, a hemostatic agent was applied to kidney after renoraphy $(\mathrm{p}=0.001)$. In a total of 5 patients (9.1\%)- only from OPN group-collecting system was repaired. Renal artery clamping was carried out in 47 of OPN (85\%) with a mean 18.8 5.1 WIT, conversely, all LPN procedures were performed without any form of ischemia. Cold ischemia through ice-slash was utilized in 23 patients of the OPN group (41.8\%). Estimated blood loss (EBL) was higher in OPN group (396 224 $\mathrm{ml}$ vs $266 \pm 179 \mathrm{ml}, \mathrm{p}<0.05)$. Accordingly, peroperative transfusion rate was also significantly higher in OPN than LPN group (22.1\% vs $3.8 \%$, respectively, $\mathrm{p}=0.04)$. Mean hemoglobin drop one day after the surgery was similar ( $1.38 \pm 0.96$ vs $1.33 \pm 1.36, \mathrm{P}=0.929)$. Postoperative complications were compared with Clavien-Dindo classification (Table 2). Complications including grade $<$ 3 and $\geq 3$ did not differ significantly between the OPN and LPN groups. Retroperitoneal bleeding and hematoma were observed in one patient on postoperative 8th day of OPN group and required surgical exploration. In another patient, kidney atrophy occurred 2 months after OPN. On the other hand, in LPN group one incisional hernia requiring surgical repairment was seen in an obese patient and one patient needed double $j$ stent placement due to persistent urinary extravasation. Mean hospital stay was significantly higher in OPN than LPN ( $4.20 \pm 1.35$ vs $2.96 \pm 0.92$ days, respectively, $\mathrm{p}<0.05$ ).

Pathological outcomes showed malignant tumor in 45 patients $(81.8 \%)$ and 17 patients $(65.4 \%)$, for OPN and LPN, respectively ( $\mathrm{p}=0.103)$. In OPN group, benign lesions were reported as angiomyolipoma $\mathrm{n}=4$ (7.3\%), complicated benign cyst $n=1(1.8 \%)$, xanthogranulomatous pyelonephritis $n=2(3.6 \%)$ and oncocytoma $n=3$ (5.5\%). In LPN group, angiomyolipoma $\mathrm{n}=3$ (11.5\%), complicated benign cyst $\mathrm{n}=3$ (11.5\%), xanthogranulomatous pyelonephritis $\mathrm{n}=1(3.8 \%)$, oncocytoma $\mathrm{n}=1(3.8 \%)$ and renal adenoma $\mathrm{n}=1(3.8 \%)$. Distribution of $\mathrm{T}$ stage was similar $(\mathrm{p}=0.99)$ for both groups (Table 3 ).

Baseline and postoperative renal functions are shown in Table 4. Preoperative creatinine value was $0.99 \pm 0.26 \mathrm{mg} / \mathrm{dl}$ in $\mathrm{OPN}$, and $0.88 \pm 0.14 \mathrm{mg} / \mathrm{dl}$ in LPN, ( $p=0.05)$. Creatinine increase after 6 months was $0.14 \pm 0.20 \mathrm{mg} / \mathrm{dl},(\mathrm{p}=0.001)$ in OPN group, while it did not significantly change in LPN $(0.06 \pm 0.18, \mathrm{p}=0.154)$. OPN patients had lower preoperative creatinine clearance levels compared to LPN group $(88.10 \pm \mathrm{ml} / \mathrm{min}$ vs $102.41 \pm 23.98 \mathrm{ml} / \mathrm{min}$, respectively, $\mathrm{p}=0.018$.) which consequently favored LPN at 6th postop month as well. Decrease in creatinine clearance at 6th month was statistically significant in OPN group, while stable in LPN ( 9.75 $\pm 12.30, p<0.05$ vs $3.89 \pm 19.17, p=0.237$ ).

Positive surgical margin was reported in 3 patients for OPN (6.6\%) and 3 for LPN (17.6\%), p=0.19. Follow-up was $72.9 \pm 41.1$ months and $47.6 \pm 32.4$ months for OPN and LPN groups, respectively $(\mathrm{p}<0.05)$. One LPN patient with negative surgical margin developed local recurrence at the end of the first year and treated with nephrectomy. In OPN group, local recurrence and a distant metastasis were observed in a patient each. Both patients received targeted therapy with tyrosine kinase inhibitor. 
Table 1. Patients characteristics

\begin{tabular}{|c|c|c|c|}
\hline & OPN $(n=55)$ & LPN $(n=26)$ & P value \\
\hline Age (years) & $57.1 \pm 13.3$ & $53.6 \pm 10.6$ & 0.245 \\
\hline \multicolumn{4}{|l|}{ Gender n (\%) } \\
\hline Female & $21(38.2)$ & $11(42.3)$ & \\
\hline Male & $34(61.8)$ & $15(57.7)$ & 0.723 \\
\hline $\operatorname{BMI}\left(\mathrm{kg} / \mathrm{m}^{2}\right)$ & $27.6 \pm 2.4$ & $28.6 \pm 5.7$ & 0.377 \\
\hline CCI & $1.8 \pm 1.3$ & $1.5 \pm 1.1$ & 0.302 \\
\hline Tumor size $(\mathrm{mm})$ & $39.7 \pm 15.6$ & $33.1 \pm 13.8$ & 0.069 \\
\hline RENAL nephrometry score & $5.6 \pm 1.6$ & $5.0 \pm 1.2$ & 0.140 \\
\hline
\end{tabular}

$\mathbf{O P N}=$ Open partial nephrectomy, $\mathbf{L P N}=$ Laparoscopic partial nephrectomy,

$\mathbf{C C I}=$ Charlson comorbidity index, $\mathbf{B M I}=$ Body mass index

Table 2. Perioperative findings

\begin{tabular}{|c|c|c|c|}
\hline & OPN $(n=55)$ & LPN (n=26) & P value \\
\hline Operation time (min) & $111.3 \pm 21.6$ & $107.5 \pm 19.5$ & 0.442 \\
\hline Hemostatic agent $\mathrm{n}(\%)$ & $30(54.5)$ & $24(92.3)$ & 0.001 \\
\hline Collecting-system repair $\mathrm{n}(\%)$ & $5(9.1)$ & 0 & 0.17 \\
\hline Warm ischemia $\mathrm{n}(\%)$ & $47(85.4)$ & 0 & $<0.001$ \\
\hline WIT (min) & $18.8 \pm 5.1$ & - & \\
\hline Cold ischemia $\mathrm{n}(\%)$ & $23(41.8)$ & 0 & $<0.001$ \\
\hline $\mathrm{EBL}(\mathrm{ml})$ & $396 \pm 224$ & $266 \pm 179$ & $<0,05$ \\
\hline Intraoperative Transfusion $\mathrm{n}(\%)$ & $12(22.1)$ & $1(3.8)$ & 0.04 \\
\hline Hemoglobin decline (post op 1st day) & $1.3 \pm 0.9$ & $1.3 \pm 1.3$ & 0.929 \\
\hline $\begin{array}{c}\text { Clavien-Dindo Score } \mathrm{n}(\%) \\
\qquad 3 \\
\geq 3\end{array}$ & $\begin{array}{l}9(16.3) \\
2(3.6)\end{array}$ & $\begin{array}{l}3(11.5) \\
2(7.7)\end{array}$ & 0.590 \\
\hline LOS (day) & $4.2 \pm 1.3$ & $2.9 \pm 0.9$ & $\mathrm{P}<0.05$ \\
\hline
\end{tabular}

$\mathbf{O P N}=$ Open partial nephrectomy, $\mathbf{L P N}=$ Laparoscopic partial nephrectomy, $\mathbf{W I T}=$ Warm ischemia time,

$\boldsymbol{E B L}=$ Estimated blood loss, $\mathbf{L O S}=$ Length of hospital stay

Table 3. Histopathological outcomes

\begin{tabular}{|c|c|c|c|}
\hline & OPN & LPN & P value \\
\hline $\begin{array}{l}\text { Benign } \\
\text { RCC }\end{array}$ & $\begin{array}{l}10(18.2) \\
45(81.8)\end{array}$ & $\begin{array}{l}9(34.6) \\
17(65.4)\end{array}$ & 0.103 \\
\hline $\begin{array}{l}\text { Pathological stage } \\
\text { T1a } \\
\text { T1b } \\
\text { T2a } \\
\text { T2b } \\
\text { T3 } \\
\text { T4 }\end{array}$ & $\begin{array}{l}32(71.2) \\
11(24.4) \\
1(2.2) \\
0 \\
1(2.2) \\
0\end{array}$ & $\begin{array}{l}13(76.5) \\
4(23.5) \\
0 \\
0 \\
0 \\
0\end{array}$ & 0.9 \\
\hline $\begin{array}{l}\text { ISUP grade } \\
1 \\
2 \\
3 \\
4\end{array}$ & $\begin{array}{l}13(29) \\
30(66.6) \\
1(2.2) \\
1(2.2)\end{array}$ & $\begin{array}{l}12(70.6) \\
5(29.4) \\
0 \\
0\end{array}$ & $<0.01$ \\
\hline $\begin{array}{l}\text { Surgical margin } \\
\text { Negative } \\
\text { Positive }\end{array}$ & $\begin{array}{l}42(93.4) \\
3(6.6)\end{array}$ & $\begin{array}{l}14(82.4 \\
3(17.6)\end{array}$ & 0.19 \\
\hline
\end{tabular}

$\mathbf{O P N}=$ Open partial nephrectomy, $\mathbf{L P N}=$ Laparoscopic partial nephrectomy,

$\boldsymbol{R C C}=$ Renal cell carcinoma, ISUP = International Society of Urological Pathology 
Table 4. Comparison of renal functions

\begin{tabular}{|lll|}
\hline & OPN & LPN \\
\hline Serum Creatinine, mg/dl & & \\
Baseline & $0.99 \pm 0.26$ & $0.88 \pm 0.14$ \\
Postoperative 6th month & $1.13 \pm 0.38$ & $0.94 \pm 0.19$ \\
Change in Creatinine & $0.14 \pm 0.2(\mathrm{p}=0.001)$ & $0.06 \pm 0.18(\mathrm{p}=0.154)$ \\
\hline Creatinine clearance, $\mathrm{ml} / \mathrm{min}$ & & \\
Baseline & $88.1 \pm 25.3$ & $102.4 \pm 23.9$ \\
Postoperative 6th month & $78.3 \pm 21.7$ & $98.5 \pm 31.9$ \\
Decline & $9.7 \pm 12.3(\mathrm{p}<0.05)$ & $3.9 \pm 19.1(\mathrm{p}=0.237)$ \\
\hline
\end{tabular}

$\mathbf{O P N}=$ Open partial nephrectomy, $\mathbf{L P N}=$ Laparoscopic partial nephrectomy

\section{DISCUSSION}

Our department is an experienced center for OPN. Conversely, laparoscopic partial nephrectomy started in 2008. Accordingly, follow-up time of OPN was longer than LPN in our series. There was not a statistically significant difference regarding tumor size, RENAL nephrometry scores, BMI and CCI between OPN and LPN groups. Operative time for both techniques was comparable as well. Gill et al examined $771 \mathrm{LPN}$ against 1029 OPN procedures and reported shorter surgery time in LPN (266 vs $201 \mathrm{~min}$ )(2). However in this study, OPN group had more cT1b tumors (31.4\% vs $8.8 \%$, respectively). In a match-paired study, Marzalek et al also found significantly shorter operative time for LPN (Median $=85 \mathrm{~min}$, Range $=70-105 \mathrm{~min}$ ) compared to OPN procedure (Median=150 $\mathrm{min}$, Range $=127-185$ $\min )(5)$.

Renal artery clamping was carried out in 47 of OPN (85\%) with a mean $18.8 \pm 5.1$ warm/cold ischemia time. Conversely, and despite being at early phase of our learning curve all LPN procedures were performed off-clamp. In Gill's study while vascular-clamp rates were similar (91\% vs $99 \%$ ), WIT was longer in LPN group (30.7 vs $20.1 \mathrm{~min}, \mathrm{p}<0.05)(2)$. On the other hand Marzalek et al determined shorter WIT in favor of LPN (23 vs $31 \mathrm{~min}, \mathrm{p}<0.001$ )(5). In our series EBL was significantly less in LPN group and despite being performed exclusively off-clamp laparoscopy of- fered a very good visualization using intra abdominal pressure to facilitate clampless PN. In addition hemostatic agents have also played a Major supporting role for the initial learning curve phase. Gill et al showed that with the application of gelatin matrix thrombin sealant postoperative hemorrhagic complications decreased from $12 \%$ to $3 \%$ (43) (6). We used hemostatic matrix in 30 of OPN (54.5\%) and 24 (92.3\%) of LPN and achieved, much less intraoperative transfusion rates with LPN compared to OPN (22.1\% vs $3.8 \%$, respectively, $\mathrm{p}=0.04$ ).

Complications including Clavien-Dindo grade $<3$ for OPN and LPN were $9(16.3 \%)$ vs. 3 (11.5\%), while grade $\geq 3$ were $2(3.6 \%)$ vs. $2(7.7 \%)$, respectively but did not differ significantly between the groups. Several studies reported postoperative complication rates for LPN and OPN ranging from $0 \%$ to $33 \%$ (6-11) and $0 \%$ to $30 \%(11-14)$, respectively. In a prospective study comparing both techniques both the rate of Clavien-Dindo grade $\geq 2$ and $\geq 3$ complications were significantly lower for laparoscopic group (15). We also

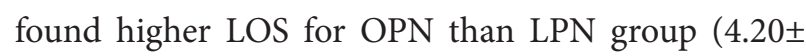
1.35 vs $2.96 \pm 0.92$ days, respectively, $\mathrm{p}<0.05$ ). These findings were in accordance with the existing literature $(5,16)$.

Our results unequivocally have shown that laparoscopic technique had more favorable functional outcomes at 6 month. It must be noted that initial creati- 
nine clearance was higher in LPN group. Nevertheless $85 \%$ of OPN was performed with a mean 18.8 minute WIT, while no patients in LPN underwent renal vascular clamping. Bleeding, a well known contributor to reduced GFR, was significantly less in LPN group as well. Lane et al showed that lower baseline GFR and longer WITs are the major predictors of postoperative renal functions. They reported that each additional minute of WIT after 20 minutes was associated with a slightly larger decrease in GFR (17). Despite still being controversial $25 \mathrm{~min}$ is suggested as a safety threshold for WIT by most of the authors (18). Thompson et al analysed 362 patients with a solitary kidney who had undergone PN using WIT and suggested optimal WIT should be under $25 \min$ (19).

In our series, we reported $18 \%$ and $34.6 \%$ benign lesions for OPN and LPN, respectively. In prior series, benign pathologies were reported ranging from $15 \%$ to $30 \%$ after partial nephrectomy $(20,21)$.This consistency was also seen in the distrubution of benign lesions. These outcomes show that current imaging modalities are still limited in differentiating benign from malignant lesions. Positive surgical margin after surgery was present in $6.6 \%$ and $17.6 \%$ for OPN and LPN, respectively. Follow-up was $72.9 \pm 41.1$ months and $47.6 \pm$ 32.4 months for OPN and LPN groups. We observed one local recurrence after both techniques and also one distant metastasis in LPN group. Nonetheless all of these recurrences and metastasis occurred in patients with negative surgical margins. In a study using National Cancer Database, positive surgical margin was found to be $4.9 \%$ and $8.1 \%$ for OPN and LPN, respectively ( $\mathrm{OR}=1.81, \mathrm{p}<0.001)(22)$. Choi et al, in a meta-analysis, have shown $2-8 \%$ positive surgical margin rate for PNs (23). In our study LPN showed higher positive surgical margine rates according to the literature. However the role of positive surgical margin on the oncological outcomes is still debatable (22). While a large retrospective study showed the relationship between PSM and local or distant relapses (24), majority of studies could not establish this association (25-27).
As a consequence, in line with majority of literature, despite of relatively higher positive surgical margine, our study revealed acceptable progresion free survival rates in LPN group for an approximately 4 years follow up.

Our study has some major limitations. First, it is a retrospective study with a limited sample size. Second, both techniques were performed by multiple surgeons. Third the indication for off clamp surgery was heavily biased .

\section{CONCLUSION}

Although LPN is accepted as a technically challenging procedure we were able to show comparable outcomes to OPN in our early learning phase with LPN. We think that these results are encouraging for surgeons planning to start with LPN. We also showed that in well selected cases, LPN with clampless technique even at the early stage of learning curve was feasible and safe and provided favorable clinical, functional and oncological outcomes.

\section{Conflict of interest}

All authors declare no conflict of interest.

\section{Financial Disclosure}

The authors declared that this study has received no financial support.

\section{Ethical Approval}

The study was approved by the Ethic Committee of Istanbul Medeniyet University, Goztepe Training and Research Hospital (Approval number: 2020/0390. Date: 2020.06.24). The study protocol conformed to the ethical guidelines of the Helsinki Declaration.

\section{REFERENCES}

1. Ljungberg B, Albiges L, Abu-Ghanem Y, et al. European Association of Urology Guidelines on Renal Cell Carcinoma: The 2019 Update. European urology 2019; 75(5):799-810.

2. Gill IS, Kavoussi LR, Lane BR, et al. Comparison of 1,800 laparoscopic and open partial nephrectomies for single renal tumors. J Urol. 2007; 178:41-46.

3. Subramonian K, DeSylva S, Bishai P, Thompson P, Muir G. Acquiring surgical skills: a comparative study of open 
versuslaparoscopic surgery. EurUrol.2004;45(3):346-51.

4. Hanzly M, Frederick A, Creighton T, et al. Learning curves for robot-assisted and laparoscopic partial nephrectomy. J Endourol. 2015; 29(3):297-303.

5. Marszalek M, Meixl H, Polajnar M, et al. Laparoscopic and open partial nephrectomy: a matched-pair comparison of 200 patients. European urology 2009; 55(5):1171-1178.

6. Gill IS, Ramani AP, Spaliviero M, et al. Improved hemostasis during laparoscopic partial nephrectomy using gelatin matrix thrombin sealant. Urology 2005; 65(3):463-466.

7. Ramani AP, Desai MM, Steinberg AP,et al. Complications of laparoscopic partial nephrectomy in 200 cases. J Urol. 2005; 173:42-47.

8. Orvieto MA, Chien GW, Tolhurst SR, et al. Simplifying laparoscopic partial nephrectomy: technical considerations for reproducible outcomes. Urology 2005; 66:976-80.

9. Link RE, Bhayani SB, Allaf ME, et al. Exploring the learning curve, pathological outcomes and perioperative morbidity of laparoscopic partial nephrectomy performed for renal mass. J Urol. 2005; 173(5):1690-1694.

10. Wright JL, Porter JR. Laparoscopic partial nephrectomy: comparison of transperitoneal and retroperitoneal approaches. J Urol. 2005; 174(3):841-845.

11. Webb CM, Kamel M, Eltahawy E, et al. A comparative study of open, laparoscopic and robotic partial nephrectomy in obese patients. Urol Ann. 2015; 7(2):231-234.

12. Lee S, Oh J, Hong SK, Lee SE, Byun SS. Open versus robot-assisted partial nephrectomy: effect on clinical outcome. J Endourol. 2011; 25:1181-1185.

13. Porpiglia F, Mari A, Bertolo R, et al. Partial Nephrectomy in Clinical T1b Renal Tumors: Multicenter Comparative Study of Open, Laparoscopic and Robot-assisted Approach (the RECORd Project). Urology. 2016; 89:45-51.

14. Han KS, Song GH, You D, Song C, et al. Comparison of Hand-Assisted Laparoscopic vs Robot-Assisted Laparo- scopic vs Open Partial Nephrectomy in Patients with T1 Renal Masses. J Endourol. 2017; 31(4):374-379.

15. Bravi CA, Larcher A, Capitanio U, et al. Perioperative Outcomes of Open, Laparoscopic, and Robotic Partial Nephrectomy: A Prospective Multicenter Observational Study (The RECORd 2 Project). Eur Urol Focus. 2021; 7(2):390-396.

16. Reifsnyder JE, Ramasamy R, Ng CK, et al. Laparoscopic and open partial nephrectomy: complication comparison using the Clavien system. JSLS. 2012; 16(1):38-44.

17. Lane BR, Babineau DC, Poggio ED, et al. Factors predicting renal functional outcome after partial nephrectomy. J Urol. 2008; 180(6):2363-2368.

18. Shen Z, Xie L, Xie W, et al. The comparison of perioperative outcomes of robot-assisted and open partial nephrectomy: a systematic review and meta-analysis. World J Surg Oncol. 2016; 14(1):220.

19. Thompson RH, Lane BR, Lohse CM, et al. Renal function after partial nephrectomy: effect of warm ischemia relative to quantity and quality of preserved kidney. Urology 2012; 79(2):356-60.

20. Tabayoyong W, Abouassaly R, Kiechle JE, et al. Variation in Surgical Margin Status by Surgical Approach among Patients Undergoing Partial Nephrectomy for Small Renal Masses. J Urol. 2015; 194(6):1548-1553.

21. Choi JE, You JH, Kim DK, Rha KH, Lee SH. Comparison of perioperative outcomes between robotic and laparoscopic partial nephrectomy: a systematic review and meta-analysis. Eur Urol. 2015; 67(5):891-901.

22. Tellini R, Antonelli A, Tardanico R, et al. Positive Surgical Margins Predict Progression-free Survival After Nephron-sparing Surgery for Renal Cell Carcinoma: Results From a Single Center Cohort of 459 Cases With a Minimum Follow-up of 5 Years. Clin Genitourin Cancer. $2019 ; 17(1): 26-31$.

23. Yossepowitch O, Thompson RH, Leibovich BC, et al. Positive surgical margins at partial nephrectomy: predictors and oncological outcomes. J Urol. 2008; 179:2158-2163. 
24. Bensalah K, Pantuck AJ, Rioux-Leclercq N, et al. Positive surgical margin appears to have negligible impact on survival of renal cell carcinomas treated by nephron-sparing surgery. Eur Urol. 2010; 57:466-471.
25. López-Costea M, Bonet X, Pérez-Reggeti J, Etcheverry B, Vigués F. Oncological outcomes and prognostic factors after nephron-sparing surgery in renal cell carcinoma. Int Urol Nephrol. 2016; 48:681-686. 